\title{
A Curious Case of Dysphagia Due to Osteophytes
}

\author{
Um Curioso Caso de Disfagia Causada por Osteófitos
}

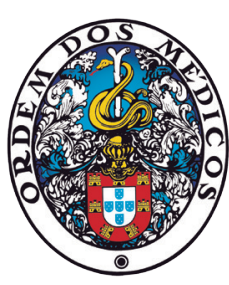

Sérgio MALTÊS $\square^{1}$, Beatriz CHAMBINO², Luís CAMPOS ${ }^{2,3}$

Acta Med Port 2022 Mar;35(3):222-223 - https://doi.org/10.20344/amp.14786

Keywords: Cervical Vertebrae; Deglutition Disorders; Osteophyte

Palavras-chave: Osteófito; Perturbações da Deglutição; Vértebras Cervicais

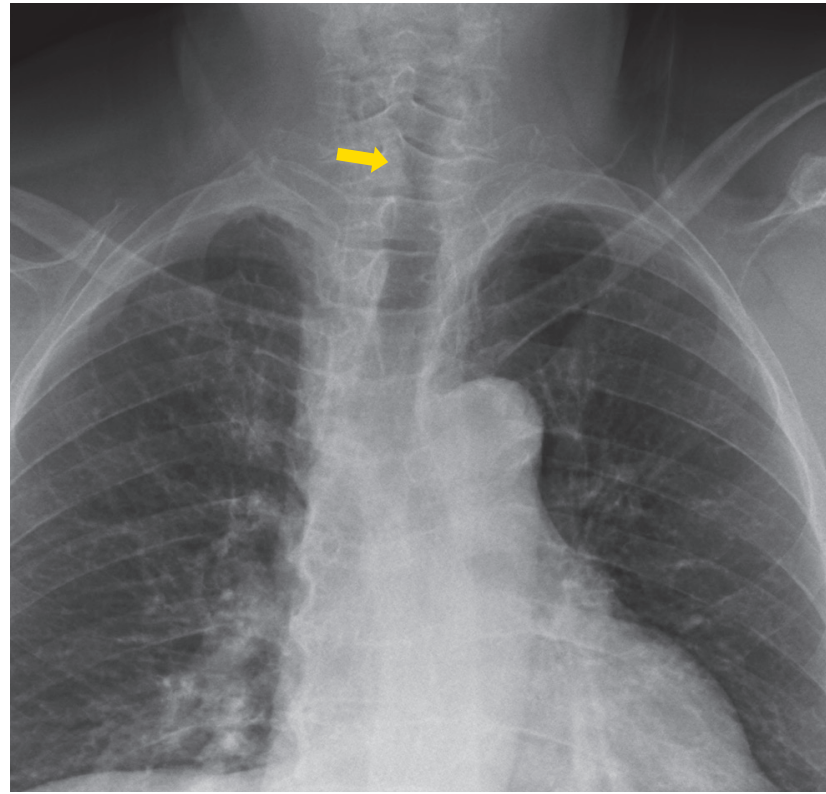

Figure 1 - Posteroanterior chest radiograph revealing a tracheal stricture (arrow)

An 80-year-old male with Parkinson's disease and partially dependent on activities of daily living (Barthel index 45) was admitted due to a first episode of community-acquired pneumonia. He also complained of long-lasting difficulty in swallowing, which his attending physician attributed to neurogenic dysphagia. Upon closer evaluation, the patient mentioned non-acute onset dysphagia, initially for liquids but now mainly affecting solid foods. The difficulty in swallowing solids was progressive, intermittent, and welllocalized to his lower neck. The chest-radiograph revealed a tracheal stricture (Fig. 1), prompting a neck computed tomography that showed an exuberant anterior osteophyte in the C4-C5 vertebrae with soft-tissue and tracheal compression (Fig. 2). The barium esophagram revealed delayed but maintained contrast progression. Although spinal osteophytes are common, occurring in one in every five elderly patients, less than $1 \%$ of osteophytes lead to dysphagia. ${ }^{1-5}$ This case illustrates how a thorough investigation is essen-

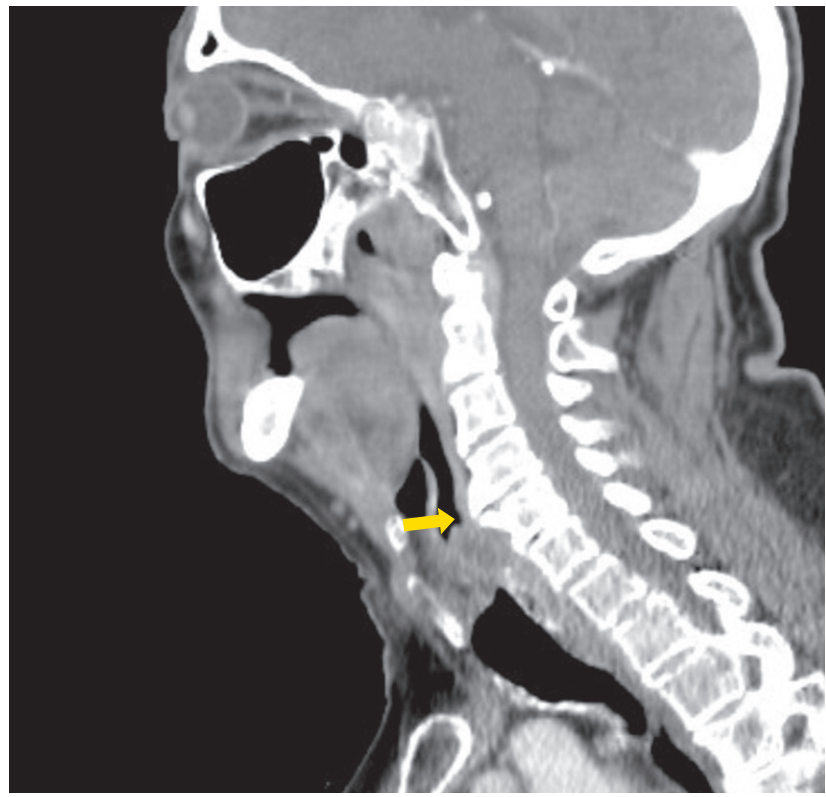

Figure 2 - Contrast-enhanced neck computed tomography with marked anterior osteophytes in the C4-C5 vertebrae (arrow)

tial to evaluate the cause of dysphagia. The patient is currently being managed through a conservative approach due to personal preference.

\section{AUTHORS CONTRIBUTION}

SM: Draft of the paper. Data interpretation. Evaluation of the patient. Responsible for the intelectual integrity of the paper.

BC: Evaluation of the patient. Data interpretation. Critical review. Responsible for the intelectual integrity of the paper.

LC: Contribution to the design of the work. Data interpretation. Critical review. Responsible for the intelectual integrity of the paper.

\section{PROTECTION OF HUMANS AND ANIMALS}

The authors declare that the procedures were followed according to the regulations established by the Clinical Research and Ethics Committee and to the 2013 Helsinki

1. Cardiology Department. Hospital de Santa Cruz. Centro Hospitalar Lisboa Ocidental. Lisbon. Portugal.

2. Internal Medicine Department. Hospital de São Francisco Xavier. Centro Hospitalar Lisboa Ocidental. Lisbon. Portugal.

3. NOVA Medical School | Faculdade de Ciências Médicas. Universidade Nova de Lisboa. Lisbon. Portugal.

$\square$ Autor correspondente: Sérgio Maltês. sergiomaltes@campus.ul.pt

Recebido: 26 de agosto de 2020 - Aceite: 26 de fevereiro de 2021 - First published: 08 de junho de 2021 - Online issue published: 02 de março de 2022 Copyright $\odot$ Ordem dos Médicos 2022 
Declaration of the World Medical Association.

\section{DATA CONFIDENTIALITY}

The authors declare having followed the protocols in use at their working center regarding patients' data publication.

\section{PATIENT CONSENT}

Obtained.

\section{REFERENCES}

1. Gupta P, Mahajan M, Sharma P, Khurana A, Bhasin I. Cricoid and cervical osteophytes causing dysphagia: an extremely rare and interesting case. Radiol Bras. 2018;51:67-8.

2. Shimizu M, Kobayashi T, Jimbo S, Senoo I, Ito H. Clinical evaluation of surgery for osteophyte-associated dysphagia using the functional outcome swallowing scale. PLoS One. 2018;13:e0201559.

3. Egerter A, Kim E, Lee D, Liu J, Cadena G, Panchal R, et al. Dysphagia secondary to anterior osteophytes of the cervical spine. Global Spine J.

\section{COMPETING INTERESTS}

The authors have declared that no competing interests exist.

\section{FUNDING SOURCES}

This research received no specific grant from any funding agency in the public, commercial, or not-for-profit sectors.

\section{5;5:e78-83}

4. Choi H, Jo G, Kim W, Do H, Kwon J, Park S. Characteristics and dlinical dourse of dysphagia caused by anterior cervical osteophyte. Ann Rehabil Med. 2019;43:27-37.

5. Kolz J, Alvi M, Bhatti A, Tomov M, Bydon M, Sebastian A, et al. Anterior cervical osteophyte resection for treatment of dysphagia. Global Spine J. 2020 (in press). doi: 10.1177/2192568220912706. 